\title{
A CRITIC APPRAISAL OF NATIONAL CENTERFOR ARCHIVES IN YEMEN-SANA'A
}

\author{
Ahmed Mohammed Ahmed Alhazmi, ${ }^{1, *}$ and Mohd.Faheem ${ }^{2}$ \\ ${ }^{1,2}$ College of Architecture, Design\& Planning College-QassimUniversity \\ Received 29 October 2013; accepted 30 December 2013
}

\begin{abstract}
The national archive works as a scientific center, fordocuments preservation, conservation and restoration in the form of paper, audio visual hold history and civilization of the country, facilitates to the researchers to gain the data easily. Building services are very complicated and difficult to maintain the documents and utilization of resources which are preserved in the building. Due to this reason, architects face lots of problems in the design of archive building. These mega projects have a significant role in preserving critical documents that are reminiscent of the eras gone by. Bearing this in mind, the establishment of national center for the conservation of documents and maintenance has been envisaged. This research will establish architectural understanding of the archive building, covering the design of National Center for Archives, analysis of plan and results is utilized as data of the research. Data has been studied and analyzed with respect to site, its elements and configuration as well as surroundings. Local architecture and demands applied to the project have been enlisted. Similar case also studied of Germany archive. Finally, on the basis of understanding and analysis, research proposes the recommendations for the architecture of archive building.
\end{abstract}

Keywords: National Center for Archives, Yemen architecture, preserve, conserve national heritage.

\section{Introduction}

The draft National Center for Documentation is one of the national projects that reflect the country's history. It is working to save important documents for reference in due course of time. It is a platform for science and for scientific research, through the study of important documents either maps, photos or documents belong history of the country, as well as with microfilm, which was used initially. Thus, the study of the conserved documents shall provide a way forward in providing the proper care (air conditioning, ventilation and appropriate preservation area).State affairs ministries and small enterprises produce innumerable documents and letters during management and operations. It is a prerequisite to keep, to reproduce and to read the different kinds of documents and records in their activities. It is quite necessary to keep historical records, manuscripts, parchments and photographic materials for a long term or indefinite preservation with modern technique and conditions.

Requirement of the archive exists in every country, as well as, wanted a building and one of the purposes of the Australian War Memorial, eventually completed in 1941, was to preserve records as well as to commemorate participation and sacrifice in war (Piggott 2012b). Architectural elements have an important role in the archive building. The Mitchell Library building in Sydney has classical features outside and inside. It was described as a 'worthy shrine' and 'national monument' on its opening in1910 (Jones 1988, 53). Also, The National Archives building in Washington was designed and constructed in the 'temple' style with symbolic intent in the 1930s (Cunningham 2005, 45). Similarly, the facility built in Brisbane for the State Archives of Queensland was the first example of a purpose-built archives repository in Australia (Ling 1998, 16; Sharman 1968, 25).

Corresponding author.

Email address:hzmiyeme@hotmail.com 


\section{Methodology}

First of all, literature study will do for understanding, what is the importance of the archive building? National centre of archive in Yemen will be studied in detail to understand the design and planning of the building on micro and macro level, which includes the analysis of plan elevation and sections. Local architecture of the Yemen, will understand through study. Further, in research will study the components of the archive of Germany. Understanding from the existing data and information will conclude that what measure should be considered in the form of conclusion and recommendations.

\section{Understanding through surrounding of site}

In figure no 1 , Site is located at Al-Dairiroad (60 meter wide) in the west and Al-Zubairi Street in the south. Well planned roads are in the south and north direction which will formulate future traffic. Southern part is captured by Ministry of foreign affairs office, on western side is parliamentary building \& opens space northern side. Al-Zubeiri Street conjoins from eastern site. Although, Ministry of foreign affairs visible from the Al-Dairi road. However the archives building will be viewed better with the background of elevated large building. It will conceive harmony with governmental buildings. The dust and pollution of air is very high on the construction site owing to emission caused by traffics. Ventilation will be maintained of the magazines through filters against dirt, dust and insects. The provision of equipment to control the chemical pollution has to be installed. Green area and good landscaping construct buffer space in between government buildings. According to annual meteorological data, the location of the national archives is idealistically located. Annual average maximum temperature is $30.5^{\circ} \mathrm{C} \&$ annual average minimum temperature is $6.8^{\circ} \mathrm{C}$. Annual average rainfall is $500 \mathrm{~mm}$. It mainly consists of a north wind and east north wind dominates in the regions of high pressure. West and east side has mountains which blocks the wind. While east and west wind is only $20 \%$ mildly in general. Average daily sunlight is $42 \%$. Percentage of sunlight is $32 \sim 53 \%$. Range of wind velocity is from $1.8 \mathrm{~m} / \mathrm{s}$ to $23 \mathrm{~m} / \mathrm{s}$.

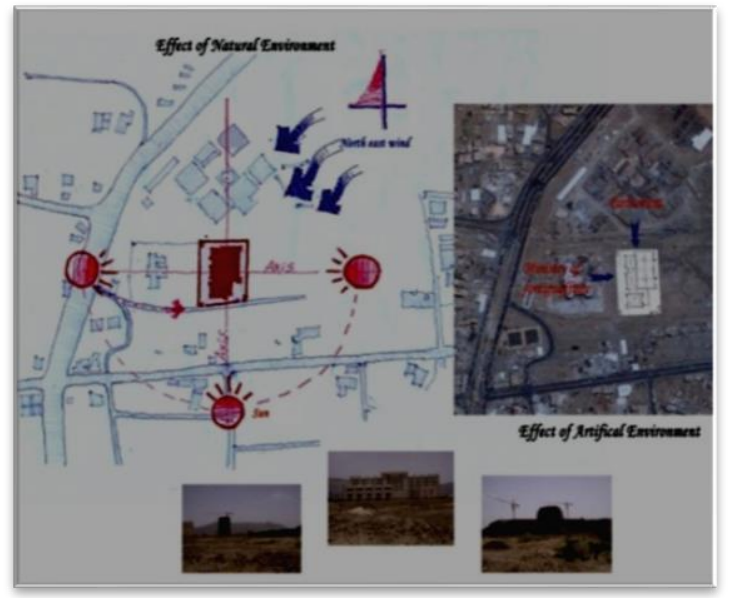

Fig. 1. Site location of Archive, Yemen

\section{Space devision and organization of archives}

Yemen National Center for Archives is largely separated into three zones on the basis of its functions. Zone A has offices and public service area. There are service rooms along with a 
A Critic Appraisal of National Center for Archives in Yemen-Sana'a

library, a cinema hall, an exhibition room, dining rooms and other rooms for readers and staff around a center of the entrance hall in the ground floor. There are also offices for its management including a general manager room from the first floor to third floor. Zone B has comprehensive magazine of each area $400 \mathrm{~m}^{2}$ (7 Floors). Archive building has two basement and seven floors There is a storage space for video\& audio records in block of north-west and other rooms for documents. Zone $\mathrm{C}$ has labs and workshop on third floors. It has workshops for video and stores on the basement, a space for lending and returning on the ground floor and labs, workshops for documents and office rooms of staffs for controlling it on the first floor.

\section{Table 1.}

Area of zones

\begin{tabular}{|c|c|c|}
\hline No & Zone A & Plan Area $\left(\mathbf{m}^{2}\right)$ \\
\hline 1 & Ground Floor & 2580 \\
\hline 2 & First Floor & 965 \\
\hline 3 & Second Floor & 1026 \\
\hline 4 & Third Floor & 1026 \\
\hline \multirow[t]{2}{*}{5} & Roof Floor & 52 \\
\hline & Total & $5649\left(\mathrm{~m}^{2}\right)$ \\
\hline \multicolumn{3}{|c|}{ Zone B } \\
\hline 1 & $3^{\text {rd }}$ Basement Floor & 4000 \\
\hline 2 & 2nd Basement Floor & 4000 \\
\hline 3 & 1st Basement Floor & 3790 \\
\hline 4 & Ground Floor & 3421 \\
\hline 5 & First Floor & 3428 \\
\hline 6 & Second Floor & 3445 \\
\hline 7 & Third Floor & 3445 \\
\hline \multirow[t]{2}{*}{8} & Roof Floor & 408 \\
\hline & Total & $25937\left(\mathrm{~m}^{2}\right)$ \\
\hline \multicolumn{3}{|c|}{ Zone C } \\
\hline 1 & 1st Basement Floor & 1373 \\
\hline 2 & Ground Floor & 1507 \\
\hline 3 & First Floor & 1335 \\
\hline \multirow[t]{2}{*}{4} & Roof Floor & 44 \\
\hline & Total & $4259\left(\mathrm{~m}^{2}\right)$ \\
\hline
\end{tabular}

\section{Organization of Functions}

The proposal of Archive Yemen is to provide the proper conservation space to meet the mission. It requires all documents, films and video-recorders and so on to preserve safely. It was satisfied sufficiently to have a comprehensive building with its characteristic of each building which it was well combined with office, workshops and magazine. It was also reasonable and innovative proposal in formation of green, path of flow for staffs and readers and carrying documents out and so on. Thus, it became as a main proposal for design of archives. Fig no 3: Describing the internal 
relationship of zone inside archive. Public movement is critically treated inside the building which will not rush in the staff movement .Public movement provided in the hall and offices (part - A) as well as republic area. Staff entry provided separately for offices and public area. Magazine (part B) linked with republic area, hall, offices and workshop especially for staff.

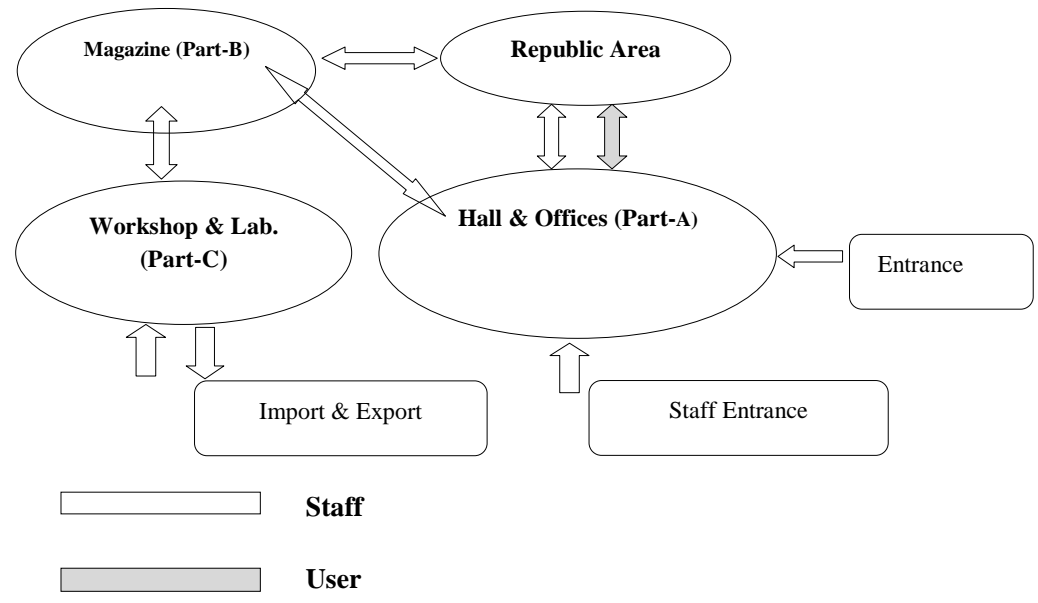

Fig. 2. Functional relations of main elements in the site

\section{Architectural characteristic of Yemen and applied elements}

Yemen has typical architecture elements. In figure no $3 \& 4$, Dominant architectural elements use in the building. They use materials such as Yagor and rich stone in mountainous districts like Sana'a and only stone in Kaukaban, Shiban and Higrah and mainly mud with making narrow opening in regions like Saada. In the hot climate, they are using mud as building material and painting (white color) conformity with their weather in regions like Hadarmaut, Shiban, Seiyun and Marib.InZubaid region it has a courtyard space in building.It is typical regions like Sana'a, Sula and Hazza with high temperature in summer and dry cool in winter. Main building material is stone \&Yagor and it is 3 or 7 storey high buildings. Space planning, like ground floor design is economical and other floors have living rooms, kitchen and dining room. Openings are narrow at ground floor and become wide at the top floor. It is decorated simply with stone and painting the windows with lime and arch type on it. Thus, it is tried to combine with architecture aspects of Yemen and apply the architectural elements meeting a modern sense of beauty.

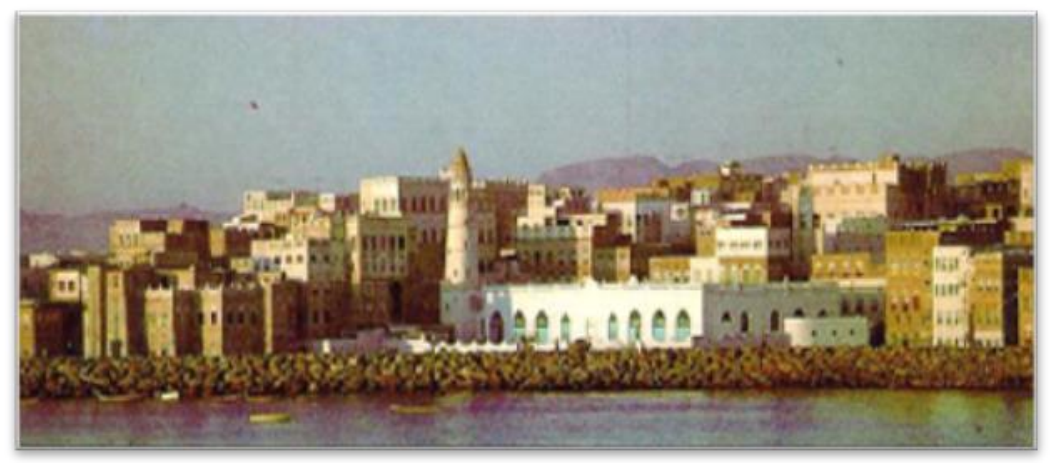

Fig. 3.Buildings' Form of Mukalla 

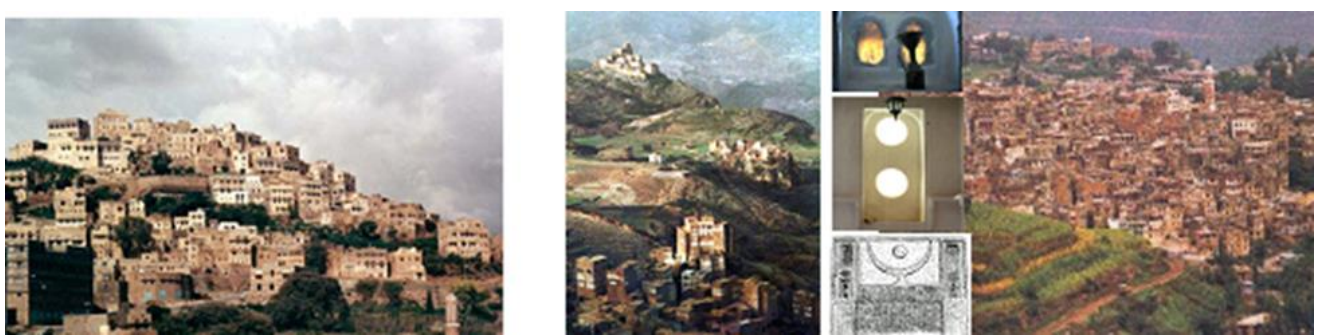

Fig.4.Buildings' Form of Western hill

\section{Architecture design of archive}

Then main function of the national center of archive is to save old documents properly. Documents preservation is the most critical part which moves through lots of experiments and process. Figure no 5, showing the building layout, dimensions are 160.9 meter long and 112 meter wide, the total area is 18124 square meter. Main entrance is dedicated to the visitors and side entrance is for the staff. Rear entrance is for the services purposes. Parking is properly provided along the boundary of the site. The design of the walkways and green area is supporting to the form of the building. The landscape is evolving the form of the building as a result all build and open spaces are making harmony. Archive building is divided in to three main parts, offices, warehouses and maintenance workshop. Office building consists of four floors which have offices, toilets, staircase etc. Building warehouses and other components are on seventh floor. Maintenance workshop are designed in the basement, it is well connected with entrance due to the transportation purposes.

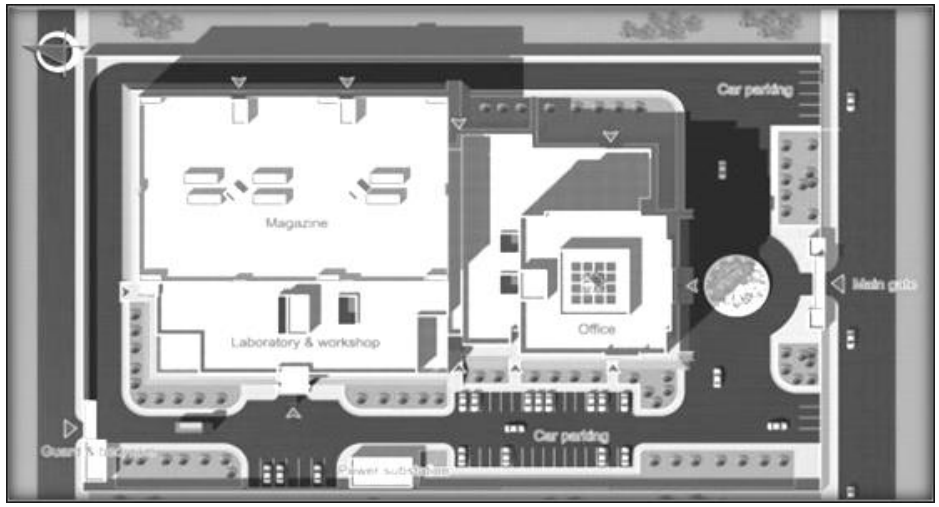

Fig.5. Site plan of Archive Yemen

Fig. 6.shows the three main parts of the main building. Administrative offices, entrance hall, reception, library and meeting room are on the ground floor. Service room and electrical room are designed in the core of the building for the safety purposes. Warehouse does not have window, day light does not require at the time of working in ware house. Ventilation is required in all room and offices. Preservation of documents room provided a reception for the purpose of safety and keeps recording. The moment of the scientists and workers should be in record so that documents safety will be handled properly. In the documentation room is provided the store rooms and spaces for the restoration and manuscripts, restoration of the old photographs spaces is design separately. 


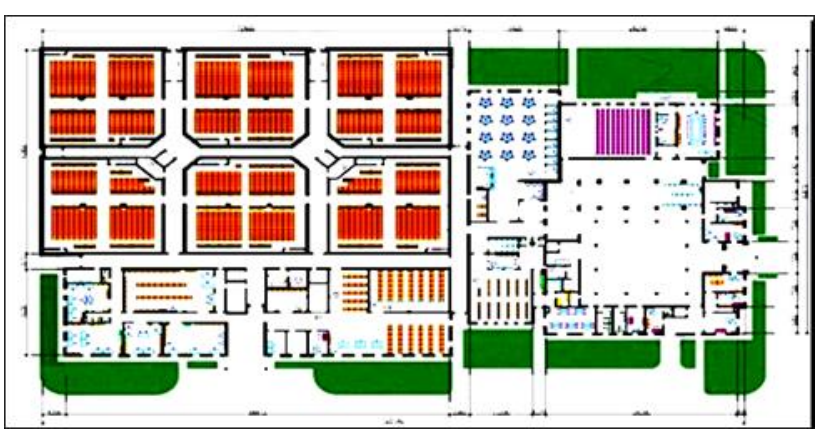

Fig. 6.Ground floor plan

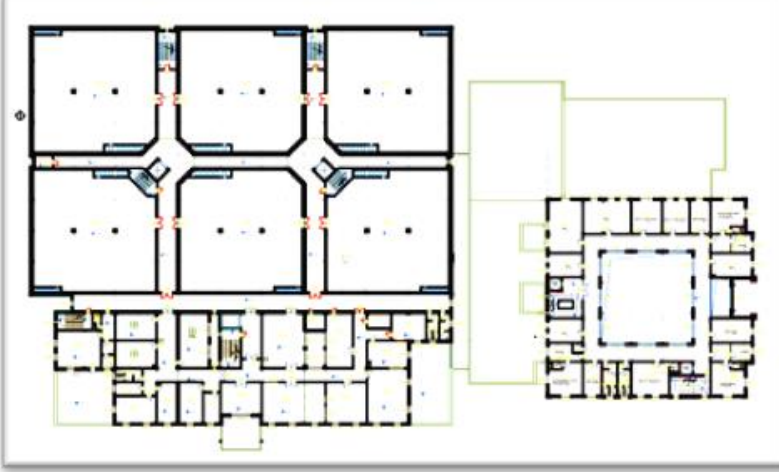

Fig.7. First Floor Plan

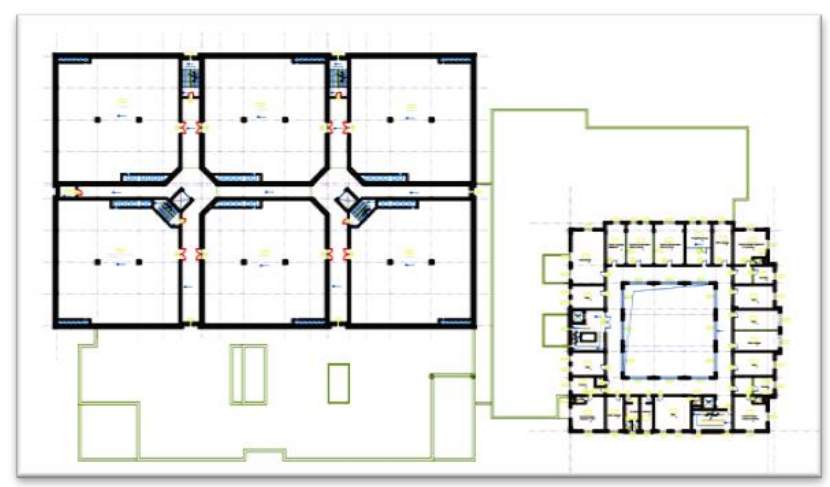

Fig. 8. Second Floor Plan 


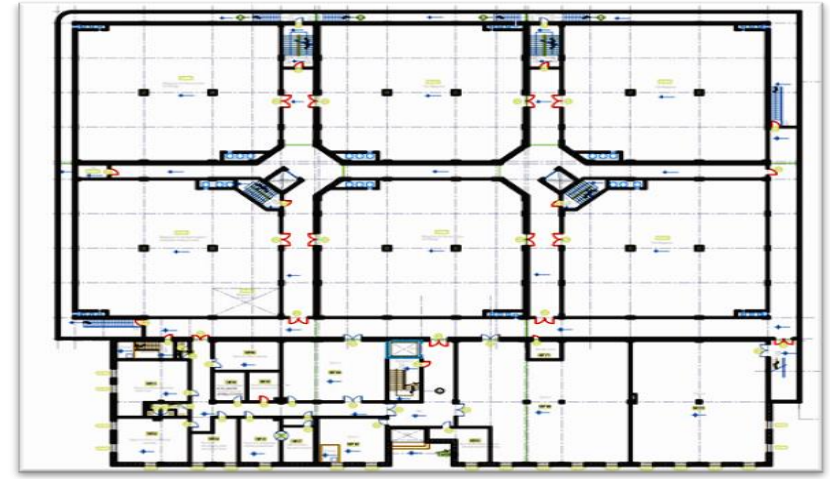

Fig. 9.1Basement Floor plan

Fig. 7; this floor has offices, displays area. Offices are designed in double loaded corridor. Ware houses are designed also along corridor. In the corridor natural light is not coming. At the junction of the corridors is staircase and lift, so that movement must be easy and comfortable for the user of the building. This area is divided into six sections; each section has staircase and lift. Some workshop are utilizing by administrative staff, so that this administrative building and workshop are designed near to each other. Maintenance and repair room is designed with workshops. Figure no 8, is almost similar to Figure no 7, the difference is that there is no administrative corridor. In this floor, library is the main component of the building with huge space and proper ventilation. Ware houses also design to save the documents vertically and horizontally.

Fig. 9.shows the basement plan which is designed for the purpose of documents and warehouses. Functionally this floor is very important floor. This floor is connected by various staircases on different locations of the floor. Proportion has been maintained in the building so that architectural vocabulary is also readable. Figure no 12, showing the architectural elements of the administrative, ware house, workshop and maintenance building .local building material has been used in the elevation of the building, cultural heritage and civilization of Yemen is representing by building form. Architectural elements are inspired from traditional building of Sanaa, which is the symbol of old architecture. Proportion and scale of the building is designed from the traditional building. Decorative elements are inspired from Old Sanaa's architecture. As well as, motifs and circular elements are inspired from old architecture. As a result, building is the modern example of the Yemen architecture, making relationship between past and future architecture of Yemen

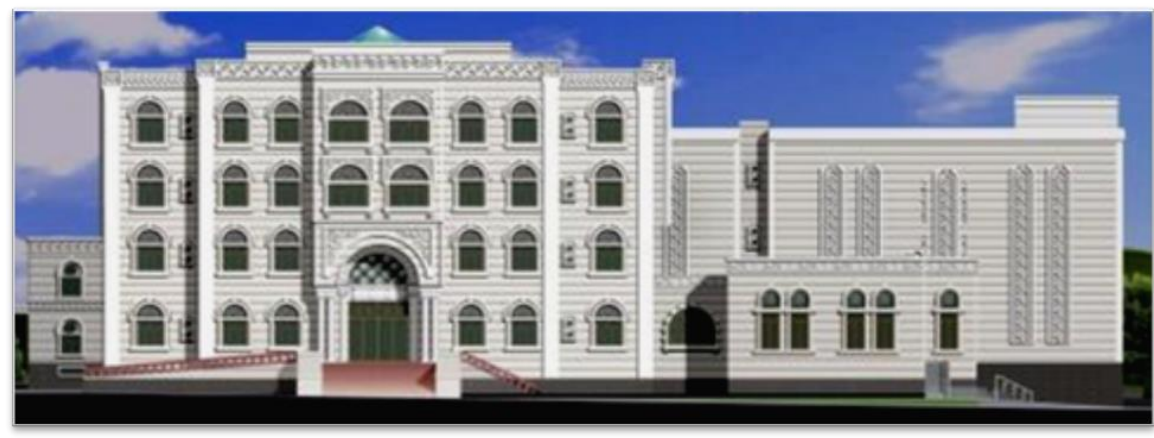

Fig. 10. Front elevation 


\section{A View of German archive}

According to the studies Germans - Archive building that consists of administrative building, stores, maintenance workshops. In figure no-11, Administrative building consists of four floors, fulfill the requirement of offices. Ground floor has entrance, reception, lecture halls and reading room, store room for bookshelves in the service lounge, gallery room near entrance hall, service stairs and elevators, restaurant, toilets and control rooms are design properly. First floor and second has offices of the various public departments and administrative offices. Third floor is the last floor contains president offices, secretarial toilets and private offices. Safety rooms are part of the ground floors for the safety purpose. A warehouse of paper documents, audio and video has been divided in different locations, according to document type and size of rack. Maintenance workshops are design on different floors according their requirements. Following pictures are describing the architecture and technical details of archive.

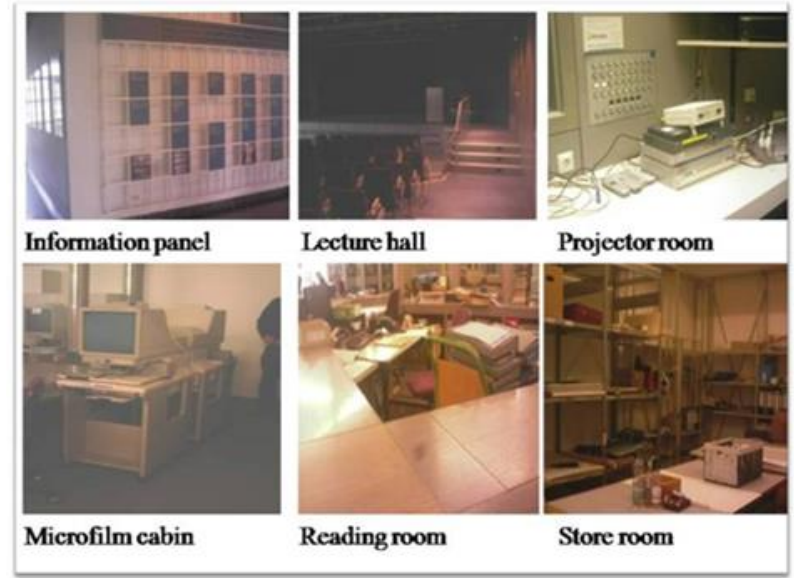

Fig. 11. Elements of archive, Germany

\section{Conclusions and recommendations for the archive building}

Through the study and analysis of the archives, the width of the corridor should not less than the 1.5 meters and water should not come in the corridor from any side. Cavity wall are very help full to control the temperature of the building without the use of electricity. Building must be design climatically and environmentally. Window should not provide in the store room. Auditorium has upholstered chairs with small table for writing. In the showroom lighting should come according documents. Sound proof door must be providing in the room. Display panel must be design properly in the entrance lobby. Projector, sound and light must be controlled from projector room. Services should be design properly which will not effect to the storage area of the documents. Cross ventilation must be provided according building requirements. Material selection must be critically, positive impact will come in the future. Building design should follow the rules of sustainability.

First of all concentrate on space planning, based on functional relationship conformity of archives. Next stage was concerned about technical designs on each parts \& elements and enlargeddrawings.Last stage covers form of the building and elements coming from tradition and modern. Completed drawings speak about functionality of the architectural design. Archive building demands the high quality construction as a national project. 
Tenders should try to keep the quality of building with a sense of function, characteristic and architecture in its construction. It should follow the demands mentioned in drawings and observe the standing rules laws of construction. It should be proved by consultant in construction to process, establishment, materials and equipments based on the technical report and specification. Finally, the anthropometric data should follow in the designing. Services and equipment consideration keep in the design so that at the time of construction they stall easily. Functionality, keep on the priority as a result, building will work properly in the future. Sustainability will improve the life and quality of the building.

\section{References}

[1.] Piggott, Michael. 2012b. "War, Sacred Archiving and C.E.W. Bean.” In Archives and Societal Provenance: Australian Essays, 119-131. Oxford: Chandos.

[2.] Jones, David J. 1988. A Source of Inspiration and Delight: The Buildings of the State Library of New South Wales Since 1826. Sydney: Library Council of New South Wales.

[3.] Cunningham, Adrian. 2005. "Archival Institutions." In Archives: Recordkeeping in Society, edited by Sue McKemmish, Michael Piggott, Barbara Reed, and Frank Upward, 34-37. WaggaWagga: Centre for Information Studies.

[4.] Ling, Ted. 1988. Solid, Safe, Secure: Building Archives Repositories in Australia. Canberra: National Archives of Australia.

[5.] Sharman, Robert. 1968. "New Building for Old: The Transmigration of the Queensland State Archives." Archives and Manuscripts 3 (7): 25-35.

\section{دراسة نقدية للمركز الوطني لحفظ الوثائق ـصنعاء اليمن-دراسة حالة}

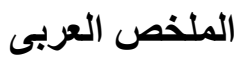

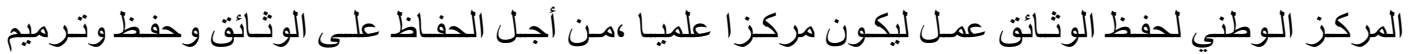

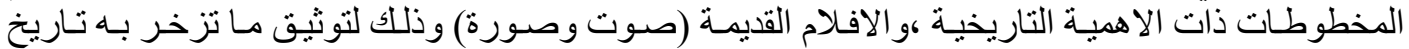

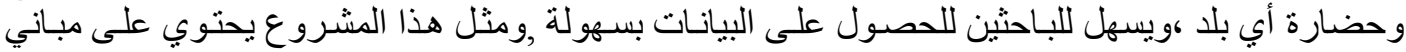

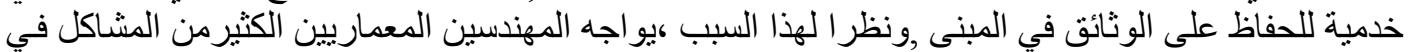

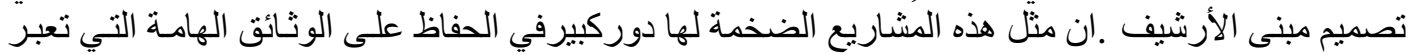

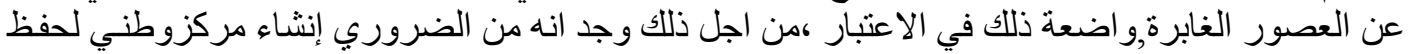

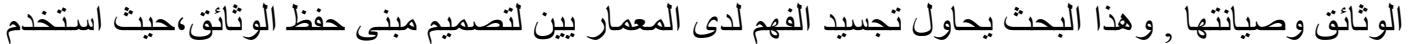

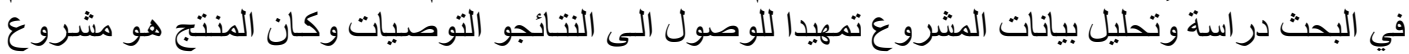

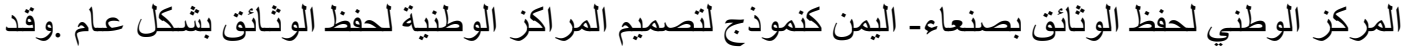

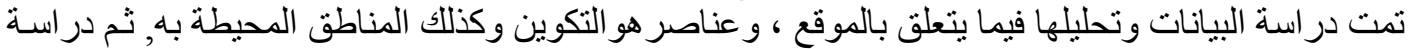

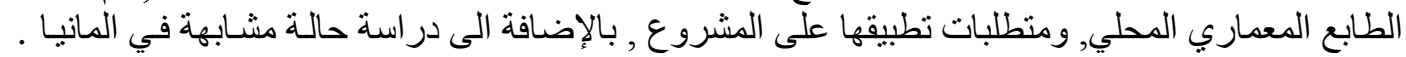

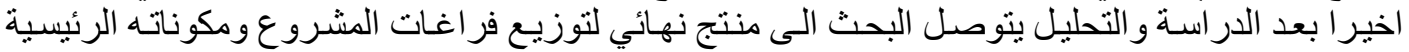

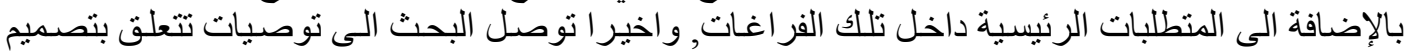

